\title{
The sociology and education of the political elite in post-Soviet Georgia
}

\author{
Avtandil A. Tukvadze ${ }^{1 *}$, Irakli Z. Ubilava ${ }^{2}$, Nadezhda V. Shulenina ${ }^{3}$, Helen Z. Gelashvili ${ }^{1}$, \\ and Nana A. Giorgashvili ${ }^{4}$ \\ ${ }^{1}$ Ivane Javakhishvili Tbilisi State University, Department of Political Science, Tbilisi, Georgia \\ ${ }^{2}$ Peoples Friendship University of Russia, Department of Policy Analysis and Management, Moscow, \\ Russia \\ ${ }^{3}$ Financial University under the Government of the Russian Federation, Department of Humanities, \\ Moscow, Russia \\ ${ }^{4}$ Caucasus International University, Faculty of Social Sciences, Tbilisi, Georgia
}

\begin{abstract}
In this paper, the main reasons that led in the post-Soviet period to the process of replacing the ruling classes with the counter-elite are analyzed. In the study, using the dialectical methodology, the authors identify trends and, following them in a logical chain, explain the order of procedures for political elites' circulation. This paper also focuses on the education factor, which significantly determines the process of formation and circulation of political elites in post-Soviet Georgia. If, in the Soviet period, one of the criteria for the formation and recruitment of local elites was local education, the trend in this direction in post-Soviet Georgia has been changed significantly. Education gained in Western, EuropeanAmerican universities has been one of the defining factors in the formation and recruitment of political elites by Georgia since its independence. However, in Georgia, mainly in Tbilisi, there are educational centers, socalled "elite schools", the vast majority of which are attended by children of new Georgians, but according to the criteria of skills, 3-4 percent of schools accept students. This is the first phase of education for junior members of local political and powerful financial groups. The second phase is the migration of graduates of these institutions to higher education institutions of Western countries to get an education. Which makes it easier for returnees to the homeland to integrate into the elite structure. In conclusion, those criteria are set out that are necessary factors for replacing the power elite with the counter-elite.
\end{abstract}

Keywords: Post-Soviet Georgia, Political Elites, Sociology, Education.

\section{Introduction}

One of the main conceptual approaches in elitology is the dichotomous division of the public system, in which differentiation of any social organism is built on antithesis, elite is a mass whose moderate, balanced relations ensure the stable functioning of the public-political system [1: 38-73].

\footnotetext{
* Corresponding author: avtandil.tukvadze@tsu.ge
} 
The dynamics of the study of socio-political processes led V. Pareto to a theoretical understanding of the "circulation of elite" [2:27-28]. According to him, society was a system of dynamic equilibrium, in which the process of changes creates cycles for social equilibrium, the flow of which depends on the nature of the circulation of elites [3: 72-73].

\section{Method}

In the case of post-Soviet Georgia, revealing aspects of the circulation tendency of ruling elites is better with the help of W. Hegel's dialectical logic and materialization of his methodology on the principles of ruling elite-counter-elite interaction. In such a way, to analyze the process of circulation of elites within it, with a dialectical approach of moving from one level to another, to a higher level. When the transformation of the power of one elite into another takes place dynamically, maintaining the balance and more or less stability of the socio-political system. It must also be said that dialectics is the doctrine of society and human thought within the unity of polar opposites [4:249], and in our case, the general laws for the development of the political system in motion.

Accordingly, the aim of our research process is to create the evolution of a phased triad of socio-political system with the conceptual use of the thesis, antithesis and synthesis. [5: 131]. With the help of such philosophical categories, it's necessary to construct such a theoretical scheme, which, based on the interaction of the elite with the counter-elite, allows us to predict political processes.

Depending on the specific methodological component of the research, in the process of analyzing this issue, the thesis of the paper will be a specific ruling elite and the idea articulated by them. Ideas that are considered as a way to meet the needs of society in a short historical period of time. As for the antithesis, its reflection materializes in the counter-elite and in propaganded ideas by them, that was widely accepted by the general public. Under synthesis, we mean the rejection of the previous pro-government elite and the practical fusion of goodness created and offered by them with the ideological postulate, which is in demand in society and which will be represented by a new ruling elite group.

The authors aim to identify the major trends and to move them into the logical chain through which the ruling classes were replaced by the counter-elites. This makes it possible to create a scientific and theoretical model that allows us to determine the natural tendency for the circulation of elite groups operating in Georgia.

\section{Results}

\subsection{General mechanisms for the circulation of political elites in Georgia}

On the basis of empirical observation on the dynamics of change and renewal of governments in post-Soviet Georgia, it has to be said that the process of replacing political leaders and elite groups mobilized around them was uneven. Observations of Georgia's political life in recent years have identified key mechanisms through which, in political life, there has been a practice of replacing the ruling elite with the counter-party. It involved the practical realization of the overthrow of the ruling group with the help of both military and nonmilitary (the "Rose Revolution") way and through it ascension of counter-elite into the system of the rule of the higher state. At the same time, the Georgian political reality is familiar with a mechanism for the replacement of power that implies legitimate methods (elections). Vivid evidence of this is the 2012 parliamentary elections [6: 60]. 


\subsection{A brief sociological-cultural analysis of Georgian society}

In general, as in any other state, the process of formation and replacement of political elites in Georgia is greatly influenced by the cultural and value components of citizens. It determines their attitude towards certain political groups. Sociological analysis of the social organization of Georgian traditional society, belongs it to the category of patriarchal and collectivist societies, that determines orientation of given electorate on a certain political person [7: 53]. This is what led to the personal orientation of Georgian voters at different times to political leaders with different agendas, which the overwhelming majority of the public linked to the solution of the most painful task under the circumstances. In this case, it is noteworthy that the line discussed above continues to this day.

\section{Discussion}

In pursuit of international legitimacy after the collapse of the Soviet Union, its former states hastily established institutions that were ill-equipped to embed democratic values. The assumption at the time was that integrity, accountability, professionalism, political competition, persuasive dialogue and compromise would permeate these new institutions. This, however, has never materialized. Instead, the economic and political uncertainty of the early 1990s, widespread poverty, the enhanced value of social safety nets, the revival of informal power structures, and the resilience of the Soviet legacy reinforced the practice of old habits, political norms and values [8: 6].

We should consider August 24, 1995, the starting point of the formation of the modern political system, when the constitution of today's independent Georgia was adopted [9: 4]. Despite numerous changes, the rules of the political game were created, on the basis of which the basic structure of the socio-political system was formed. Therefore, the process of observing the changes of the ruling elites covers fairly just the period from which the structural formation of the modern political system began. Consequently, our aim is to analyze the political process since 1995, when the political class consolidated around E. Shevardnadze. They controlled both the executive branch and the parliamentary institution, with the constitutional majority of the ruling party - "The Union of Citizens of Georgia."

The first such leader was the second President of Georgia, E. Shevardnadze, who came to the power through the overthrow of the first president of Georgia. This was the period when civil war was raging in Georgia in parallel to the ethnic conflicts. Shevardnadze's political figure was percepted as a guarantee of stability by broader layers of the population because of the complete chaos and socio-economic poverty of the country. He had a huge political experience working as a foreign minister in Moscow. In general, in provincial societies orientation on persons working abroad is not a novelty, and firmly rooted in the genetics of traditional Georgian society. Shevardnadze was a prominent member of the old Soviet nomenklatura. From 1972-1985, before his assignment as Minister for Foreign Affairs of the Soviet Union, he was the First Secretary of the Central Committee of the Communist Party of the Georgian Soviet Socialist Republic and the actual governor of the Republic [10: 189]. This situation, in turn, has had a profound effect on the rise of E. Shevardnadze and the elite groups around him in the highest vertical structure of government. But it should be noted that loyalty to the leader, and not professionalism or the ability to think creatively, were the main criterion for success. Another Georgian author, S. Giorgadze, confirms that loyalty was very important for E. Shevardnadze. According to him, Shevardnadze held on to the wornout Soviet elite system in order to maintain his rule and relied on the old structure of the communist nomenclature [11:37]. Finally, president E. Shevardnadze's work minimally, but still fulfilled the mission that the Georgian electorate has focused on. He was able to stabilize the political system and the public order in general, followed by two election cycles. 
However, as in any society, the process of social growth is always associated with the end of the old and the beginning of a new socio-political cycle, which raises different needs in the consciousness of the electorate.

In such circumstances, in the political arena comes up M. Saakashvili with renewed ideas. Like his predecessor, his charisma and political capital was accumulated thanks to his American career. He was perceived by the people as a politician, who studied abroad and was able to transform the social-political system and transplant Western lifestyle. At the time, for the vast majority of Georgian voters, Western lifestyle into the Georgian reality was perceived as an absolute good, which should be achieved primarily through the elimination of total corruption in the country.

In the process of implementing Saakashvili's policy, the most important communication card with the electorate was the image of an anti-corruption fighter and reformer. All this, together with Western (American) support, led to the capture of a power vertical by him and by his affiliated political elite.

Like President Shevardnadze, the political activity of Georgia's third president could not last more than two election cycles. However, despite the autocratization of the governance system, rigid authoritarianism and shameful defeated in the 2008 war, the process of reforming and transforming the socio-political system realized by him, along with many negatives, brought some small but still positive elements. It is about reducing the level of corruption and the institutionalization of the socio-political system.

By the end of the second election cycle, raised a new demands of society, which was related to the democratization of the political system. Most important is that he linked country's economic development with the transition to industrialization to a person who earned his billions in Russia. This is evidenced by the promise to build several hundred enterprises made during the election campaign.

It must be said that despite the personification of the political system and informal governance, which emphasized by different policy experts, the steps towards democratization and socio-political pluralization are clearly visible [12: 890].

Operationalization of dialectical methodology on the circulation procedures of Georgian political elites gives us possibility to make the following conclusion: In the first case the idea of stability being rebranded by the pro-government elite mobilized around E. Shevardnadze was rejected by the counter-elite, with the ideas of anti-corruption and institutionalization of the country. In second case stability of the political system was achieved by institutionalization of the system and a significant reduction level of corruption. This synthesis factor has led to the evolution of Georgia's socio-political system and consequently, he was elevated from the lower hierarchical stage of development to the higher stage of the dialectical ladder.

As for the political analysis of today's political leader's policy, 2012 is considered the beginning of a new political class, during which the counter-elite rejected predecessor ruling elite.

If we analyze the changes of political elites in Georgia in a spiral line, we come to the conclusion that the expiration of two parliamentary elections is a necessary condition for the circulation of each ruling elite. In each case, we see the rejection of the previous government. The work of all of them has always been associated with materialization of new and crucial ideas in the political system at that time. Therefore, the start of a new governance cycle played a positive role in moving to a higher and more advanced level of the socio-political system.

If we analyze the timing of the circulation of the previous ruling political classes and generalize them to the current political power of the government, then it is likely that this electoral cycle will be the last for the current ruling elite.

At the same time, in the formation of a political force opposed to the existing ruling class and its subsequent transformation into ruling elite the European-American education of their 
members played a special role; which was especially evident from the period after Mikheil Saakashvili came to power through the "color revolution". During the rule of the third president of Georgia, the criteria for selection the political elite was mainly foreign education and young age; He expelled members of the older generation (over 50) from the political scene as well as from universities [13: 98].

The same trend continues in the conditions of the ruling elite of the Georgian Dream party. The analysis of the first platoon of parliamentary list of the political party "Georgian Dream" shows that there are 14 lawyers in the party, of which 8 have an academic degree of doctor, one political scientist, 2 international relations specialists (both have academic degree of doctor), three economists. More than half of them have been educated in leading European universities [14]. As for the chairman of the party, he is an exception, who was educated in Russia and had an academic degree of doctor in economics.

Also, when studying the issues of recruitment-circulation of Georgian political elites, the focus should be on the fact that in Georgia, mainly in Tbilisi, there are so called "elite schools" [15], in the vast majority of which mainly the children of "new Georgians" (members of the elite) study; because access to education in these institutions is associated with high financial costs, it is only 3-4 percent of the total number of students in the country. It mainly includes the children of the financial and political elite, which greatly contributes to the structural renewal and recruitment of the political elite, based only on members from wealthy families, such as the families of political and powerful financial circles.

\section{Conclusion}

After a brief analysis of historical and political peripetas, there is a need to make political prediction. It is important to point out the common characteristics that defined the preconditions for coming to power of the previous and even current political leader.

- Objective political processes within the political system, at the end of second election period, lead to appearance of a charismatic political leader, which with a consolidated elite group, comes up in the politics with the most demanding and acceptable idea for the absolute majority of society at that time;

- In the case of all political leaders accumulation of public-political and financial capital is related to its activities abroad (Russia or the United States).

- Towards the ruling class, around an antagonistically minded political leader was mainly consolidated a wide circle of people with a European-American education, which is one of the main criteria for incorporation into an elite structure.

- As a whole, their term of office is marked by two election terms, in which the period of staying in power is practically change in the regressive direction.

- The process of delegitimizing the ruling political elite reaches its full apogee at the end of the second election cycle.

Political-sociological analytics outlined in the theoretical framework, gives us possibility to prove that any political force and leader must fall within the five criteria set out above in order to gain power.

\section{References}

1. O.V. Gaman-Golutvina, Political science, 2, 38-73 (2016)

2. O. Kryshtanovskaya, Anatomiya russkoy elity [Anatomy of the Russian elite] (Zakharov, Moscow, 2005)

3. A. Naronskaya, Discourse, 3, 72-78 (2018)

4. E. Kodua, Dialectical Materialism (Tbilisi University Press, Tbilisi, 1970) 
5. O. G. Danilyan, Filosofiya prava [The philosophy of law] (Eksmo, Moscow, 2007)

6. B. Chedia, Central Asia and the Caucasus, 13(4), 59-70 (2012)

7. I.D. Ubilava, N.V. Shulenina, Political Science Issues, 1(29), 50-57 (2018)

8. C. Gherasimov, Political Elite Renewal in Georgia, Moldova and Ukraine. Chatham House (2019). Accessed on: December 10, 2020. [Online]. Available:

https://www.chathamhouse.org/sites/default/files/2019-05-14Political\%20Elite\%20Renewal.pdf

9. E. Shevardnadze, For an independent, integral, democratic Georgia (Tbilisi, 1995)

10. Z. Chiaberashvili, G. Tevzadze, Power Elites in Georgia: Old and New, in After Shevardnadze: Georgia Security Sector Governance after the Rose Revolution, Chapter 2, (2005). Accessed on: December 20, 2020. [Online]. Available: https://www.files.ethz.ch/isn/105015/fulltext.pdf

11. S. Giorgadze, The Influence of Political Culture on Political Elite: The Case of PostSoviet Georgia, Master's Dissertation (Central European University, Budapest, 2015)

12. V. M. Dolidze, Post-Soviet Studies, 2(1), 885-892 (2019)

13. N. Mossaki, MEMO Journal, 9, 93-104, (2015)

14. L. Pertaya, Dream Team of "Georgian Dream": tactics and strategy (2020). Accessed on: September 20, 2020. [Online]. Available: https://ru.netgazeti.ge/3441/

15. B. Namchavadze, We spend more and more low quality school education. Transparency International (2018). Accessed on: October 14, 2020. [Online]. Available:

https://www.transparency.ge/sites/default/files/we_spend_more_and_more_on_low_qu ality_school_education.pdf 